\title{
Planting Date and Cultivar Effects on Soybean Yield, Seed Quality, and Phomopsis sp. Seed Infection
}

J. A. Wrather, University of Missouri-Delta Center, Portageville 63873; D. A. Sleper, University of Missouri, Columbia 65211; W. E. Stevens and J. G. Shannon, University of Missouri-Delta Center; and R. F. Wilson, United States Department of Agriculture, Raleigh, NC 27695

\begin{abstract}
Wrather, J. A., Sleper, D. A., Stevens, W. E., Shannon, J. G., and Wilson, R. F. 2003. Planting date and cultivar effects on soybean yield, seed quality, and Phomopsis sp. seed infection. Plant Dis. 87:529-532.

Incidence of Phomopsis seed decay is frequently high and quality low in seed from early-maturing maturity group III and IV soybean cultivars planted in early to mid-April in the southern United States. Cultivars resistant to this disease have not been available until the recent release of germ plasm lines SS 93-6012 and SS 93-6181. Our objective was to determine the effects of planting dates with these lines and one Phomopsis seed decay-susceptible soybean cultivar, Asgrow 3834, on seed infection by Phomopsis spp. and on yield and the correlation between percentage of Asgrow 3834 infected with Phomopsis spp. and seed quality. Generally, yields averaged over years were significantly greater for mid-April than mid-June plantings, and yields of cultivars were similar within a planting date. Soybean lines SS 93-6012 and SS 936181 were highly resistant to Phomopsis seed decay compared with the susceptible cultivar, Asgrow 3834. There was a significant, negative correlation between germination of seed from mid-April plantings of Asgrow 3834 and percentage of these seed infected with Phomopsis spp. Moreover, there were significant correlations between fatty acid composition of Asgrow 3834 seed and the percentage of these seed infected with Phomopsis spp. This altered composition of fatty acids may be responsible for reduced quality of oil derived from seed infected with this fungus. Phomopsis seed decay-resistant soybean lines SS 93-6012 and SS 93-6181 should be useful in breeding programs focused on developing high-yielding cultivars resistant to this disease.
\end{abstract}

Additional keywords: fatty acid composition, Glycine max, percent oil, percent protein, seed germination

In the southern United States, drought stress has been a common yield-limiting factor for soybean, Glycine $\max (\mathrm{L}$.) Merr., especially if drought occurred during bloom and pod fill. In this region, maturity group (MG) V and VI soybean cultivars commonly are planted from mid-May to mid-June, and the plants flower and produce seed from late July to early September, when droughts most often develop. The Early Soybean Production System (ESPS) was designed to help growers in the south avoid late-July through earlySeptember drought damage to soybean (9). The success of this system is dependent on planting early-maturing cultivars (cultivars

Corresponding author: J. A. Wrather

E-mail:wrather@missouri.edu

This research was, in part, supported by the Missouri Agricultural Experiment Station.

This project also was supported by the Missouri Soybean Farmer Checkoff through the Missouri Soybean Merchandising Council grant no. 99-185.

Accepted for publication 6 December 2002.

Publication no. D-2003-0226-01R

(C) 2003 The American Phytopathological Society from MG III to IV) earlier than normal (early to late April rather than mid-May to mid-June), so that pod fill is mostly complete before late-summer droughts develop. Advantages of the ESPS have been observed in Arkansas (21), Mississippi (9), Texas (17), and Missouri (24). Unfortunately, seed infection with Phomopsis spp. was high in some MG III and IV cultivars planted during mid-April in Arkansas (14) and Missouri (24).

Phomopsis seed decay is endemic throughout most soybean-growing states in the United States (20), but yield losses from this disease vary among years and among regions (25). Phomopsis seed decay suppressed yield, reduced the quality of seed used for planting by reducing germination, and lowered the quality of seed used for processing $(19,24)$. The quality of oil derived from seed infected with Phomopsis spp. was lower than that from healthy seed (10), but the effects of Phomopsis seed decay on fatty acid composition of seed has not been determined.

The usefulness of the ESPS would be greater if Phomopsis spp.-resistant soybean cultivars were available for planting (14,24). Fortunately, a Phomopsis seed decay-resistant soybean line, MO/PSD-
0259, was registered in 1993 (15). Two high-yielding soybean lines, SS 93-6012 and SS 93-6181, resistant to Phomopsis seed decay were developed from a cross of MO/PSD-0259 and Asgrow 3322. The objective of this research was to determine the effects of planting dates of soybean lines SS 93-6012 and SS 93-6181 and one Phomopsis seed decay-susceptible cultivar, Asgrow 3834, on infection of seed by Phomopsis spp. and on yield and the correlation between percentage of Asgrow 3834 seed infected with Phomopsis spp. and seed quality.

\section{MATERIALS AND METHODS}

Experiment plot management. Plots were established in 1998, 1999, and 2000 near Portageville, $\mathrm{MO}$ on a silt loam soil consisting of $34 \%$ sand, $50 \%$ silt, and $16 \%$ clay. Prior to planting each year, the field was disked twice, and row beds $(75-\mathrm{cm}$ spacing) were formed. The top $10 \mathrm{~cm}$ of the beds was pushed off just prior to planting to form a flat-top ridge. Soybean cv. Asgrow 3834 (MG III) and soybean lines SS 93-6012 (MG III) and SS 93-6181 (MG IV) were planted, respectively, on 15 April, 15 May, and 15 June 1998; on 16 April, 17 May, and 14 June 1999; and 21 April, 16 May, and 15 June 2000. Each four-row plot was $3 \mathrm{~m}$ wide and $7.6 \mathrm{~m}$ long, and 26 seed were planted per meter of row. All plots received a pre-emergence application of imazaquin (American Cyanamid Co., Agriculture Division, Wayne, NJ) at 0.14 $\mathrm{kg}$ a.i./ha and alaclor (Monsanto Co., Agriculture Group, St. Louis, MO) at 0.4 $\mathrm{kg}$ a.i./ha. Plots were cultivated once and hand-weeded as necessary. Plots were located in a different area of the same field each year to avoid problems caused by repeated planting in the same area, and these areas were planted to soybean prior to this test. Plots were not irrigated. A split-plot design with four replications included three planting dates as main plots and soybean cultivars randomized within the main plots as subplots.

Seed analysis. Each year, the middle two rows of each plot were harvested at maturity, and seed moisture was measured. Yield of each plot was adjusted to $13 \%$ moisture. A 500-g sample of harvested seed from each plot was stored in a paper bag at $25^{\circ} \mathrm{C}$ and analyzed within 30 days for percentage of seed infected with $\mathrm{Pho}$ mopsis spp. (1998 to 2000) and seed qual- 
ity traits (1999 to 2000). In all, 100 arbitrarily chosen seed from each plot were surface-disinfested in $0.5 \%$ sodium hytilled water, and placed on acidified $(\mathrm{pH}$ 4.5) potato dextrose agar in petri dishes (22). Five seed were placed on each culture dish and incubated under fluorescent lights at $25^{\circ} \mathrm{C}$. Seedborne fungi were identified based on morphological characteristics 7 days later (2,20). During 1999 and 2000, germination of seed from all plots was determined. Germination of 100 arbitrarily chosen seed from each plot was tested according to procedures adopted by the Association of Official Seed Analysts (6). During 1999 and 2000, $20 \mathrm{~g}$ of seed from the Asgrow 3834 plot planted in mid-April were tested for protein and oil by nearinfrared analysis. Seed from these same plots also were tested for fatty acid composition following the method described by Rebetzke et al. (16).

Analysis of data. Statistical analyses of treatment effects on seed yield, percentage of seed infected with Phomopsis spp., and percent germination were performed using SAS Mixed Model procedures (SAS Institute, Cary, NC). The Mixed Model procedure provides Type III $F$ values but does not provide mean square values for each element within the analysis or the error terms. Mean separation was evaluated pochlorite for $5 \mathrm{~min}$, rinsed in sterile dis-

through a series of protected pairwise contrasts among all treatments (18). Probability levels greater than 0.05 were categorized as nonsignificant. Data from 1998 and 2000 were used in the analysis of effects of planting date and cultivar on percent seed infected with Phomopsis spp. because few seed harvested from plots in 1999 were infected with this pathogen, except those from Asgrow 3834 planted in mid-April. Percent seed infected with Phomopsis spp. during 1998 and 2000 were transformed before analysis, $(X+0.5)^{1 / 2}$, where $X$ is the original percent infection (18), because the percentage of seed from all plantings of lines SS 93-6012 and SS 93-6181 infected with Phomopsis spp. was very low $(<10 \%)$ during both years. The response variables percentage of oil and protein in seed, seed germination, and content of palmitic, stearic, oleic, linoleic, and linolenic in seed from mid-Aprilplanted Asgrow 3834 were regressed against the explanatory variable percentage of seed infected with Phomopsis spp. (7). The PROC CORR procedure of the SAS software was used for this.

\section{RESULTS}

Yields averaged over planting dates and cultivars were greater in 2000 and less in 1998 and 1999 (2.37, 0.96, and $0.53 \mathrm{Mg}$ $\mathrm{ha}^{-1}$, respectively). Differences in yields

Table 1. Analysis of variance for yield, percent Phomopsis sp. infection, and percent seed germination for year, cultivar, and planting date ${ }^{z}$

\begin{tabular}{lccc}
\hline & \multicolumn{3}{c}{$\boldsymbol{P r} \geq \boldsymbol{F}$} \\
\cline { 2 - 4 } Source of variation & Yield & Seed infected $(\%)$ & Germination (\%) \\
\hline Year (Y) & $<0.0001$ & 0.0244 & 0.0187 \\
Planting date (PD) & 0.0019 & $<0.0001$ & $<0.0001$ \\
Y $\times$ PD & 0.0002 & 0.0017 & 0.0059 \\
Cultivar $(C)$ & 0.3356 & $<0.0001$ & $<0.0001$ \\
Y $\times$ C & 0.4055 & 0.0418 & $<0.0001$ \\
PD $\times$ C & 0.0338 & $<0.0001$ & $<0.0001$ \\
Y $\times$ PD $\times$ C & 0.3916 & 0.6983 & 0.5110
\end{tabular}

${ }_{\mathrm{z}}$ Years for yield were 1998, 1999, and 2000. Years for percent seed infected with Phomopsis spp. were 1998 and 2000. Years for percent seed germination were 1999 and 2000. Cultivars were Asgrow 3834, SS93-6012, and SS93-6181. Planting dates were mid-April, mid-May, and mid-June.

Table 2. Planting date and soybean cultivar effects on yields $\left(\mathrm{Mg} \mathrm{ha}^{-1}\right)$, percent Phomopsis sp. infection of seed, and germination of harvested seed averaged over years ${ }^{z}$

\begin{tabular}{lccl}
\hline & \multicolumn{3}{c}{ Planting dates } \\
\cline { 2 - 4 } Cultivars & mid-April & mid-May & mid-June \\
\hline Yields $\left(\mathrm{Mg} \mathrm{ha}^{-1}\right)$ & $1.43 \mathrm{ab}$ & $1.26 \mathrm{bcd}$ & $1.15 \mathrm{~cd}$ \\
Asgrow 3834 & $1.29 \mathrm{bc}$ & $1.32 \mathrm{bc}$ & $1.17 \mathrm{~cd}$ \\
SS 93-6012 & $1.54 \mathrm{a}$ & $1.32 \mathrm{bc}$ & $1.12 \mathrm{~d}$ \\
SS 93-6181 & & & \\
Seed infection (\%) & $41.5 \mathrm{a}$ & $32.4 \mathrm{~b}$ & $8.1 \mathrm{c}$ \\
Asgrow 3834 & $7.1 \mathrm{c}$ & $2.3 \mathrm{def}$ & $1.2 \mathrm{f}$ \\
SS 93-6012 & $3.4 \mathrm{de}$ & $3.6 \mathrm{~d}$ & $1.5 \mathrm{ef}$ \\
SS 93-6181 & & & $88.9 \mathrm{ab}$ \\
Germination & $39.1 \mathrm{e}$ & $56.0 \mathrm{~d}$ & $94.4 \mathrm{a}$ \\
Asgrow 3834 & $67.5 \mathrm{c}$ & $80.9 \mathrm{~b}$ & $93.1 \mathrm{a}$ \\
SS 93-6012 & $84.5 \mathrm{ab}$ & $88.6 \mathrm{ab}$ & $\mathrm{P}$ \\
SS 93-6181 &
\end{tabular}

${ }^{\mathrm{z}}$ Years were 1998 to 2000 for effects on yields, 1998 and 2000 for effects on percent Phomopsis sp. seed infection, and 1999 and 2000 for effects on germination of harvested seed. Values followed by the same letter are not significantly different $(P=0.05)$. among years were due to differences in rainfall for June through August each year. Rainfall for these months during 1998, 1999, and 2000 were $22.8 \mathrm{~cm}, 15.0 \mathrm{~cm}$, and $42.4 \mathrm{~cm}$, respectively. Plant populations averaged over treatments, 205,000 plants $\mathrm{ha}^{-1} 4$ weeks after emergence, were similar among years (data not shown) and were not responsible for yield differences among years.

Analysis of variance for yield, percent Phomopsis sp. seed infection, and germination of harvested seed indicated that there was a significant planting datecultivar interaction (Table 1). Generally, yields averaged over years were significantly greater for mid-April than mid-June plantings, and yields of cultivars and lines were similar within a planting date (Table 2). The percentage of Asgrow 3834 seed infected with Phomopsis spp. was significantly greater than for lines SS 93-6012 and SS 93-6181 seed for all planting dates (Table 2). The percentage of Asgrow 3834 seed infected with Phomopsis spp. was significantly greater for the mid-April than mid-May and significantly greater for the mid-May than mid-June plantings. Generally, germination of seed from mid-June plantings was significantly greater than seed from mid-April plantings and significantly greater for lines SS 93-6012 and SS 93-6181 than for Asgrow 3834 planted mid-April and mid-May (Table 2). Germination of seed from mid-June plantings for all cultivars was similar.

Analysis of variance for percent Phomopsis sp. seed infection and for germination of seed indicated that there was a significant year-cultivar interaction (Table 1). The percentage of Asgrow 3834 and line SS 93-6012 seed infected with Phomopsis spp. was significantly greater for 2000 than 1998 (Table 3). The percentage of Asgrow 3834 seed infected with Phomopsis spp. was significantly greater than lines SS 93-6012 and SS 93-6181 for 1998 and 2000. Germination of Asgrow 3834 seed was significantly greater for 1999 than 2000, and germination of lines SS 93-6181 and SS 93-6012 seed was significantly greater than Asgrow 3834 for 1999 and 2000 (Table 3).

Analysis of variance for yield, percent Phomopsis sp. seed infection, and germination of seed indicated that there was a significant year-planting date interaction (Table 1). Yields were significantly greater for all planting dates for 2000 than for 1998 and 1999 (Table 4). Yields were significantly greater for the mid-April than mid-May plantings in 2000 but not in 1998 and 1999. The percentage of seed infected with Phomopsis spp. was significantly greater for the mid-April and mid-May plantings for 2000 than for 1998 (Table 4). The percentage of seed infected with Phomopsis spp. was significantly greater for the mid-April than mid-May planting in 2000 and for the mid-April than mid-June 
planting in 1998 and 2000. Germination of seed from the mid-April planting was significantly greater for 1999 than 2000 and significantly greater for the mid-June than mid-April and mid-May plantings in 1999 and 2000 (Table 4).

There were no significant correlations between the percentage of seed infected with Phomopsis spp. and the percentage of oil and protein in seed from mid-Aprilplanted Asgrow 3834 (Table 5). There was a significant negative correlation between the percentage of seed infected with Phomopsis spp. and germination of seed from mid-April plantings of Asgrow 3834. There was a significant and negative correlation between the percentage of seed infected with Phomopsis spp. and palmitic acid and oleic acid composition. There was a significant and positive correlation between the percentage of seed infected with Phomopsis spp. and linoleic acid and linolenic acid composition. There was no correlation between the percentage of seed infected with Phomopsis spp. and stearic acid composition of seed.

\section{DISCUSSION}

In this study, similar yields were observed for MG III and IV cultivars between mid-April and mid-May plantings in 2 of 3 years (1998 and 1999) in this nonirrigated field. These were dry years. Yields were significantly greater for mid-April than mid-May plantings in 1 of 3 years (2000). Rainfall for June through August was greater for $2000(42.4 \mathrm{~cm})$ than $1998(22.8$ $\mathrm{cm})$ and $1999(15.0 \mathrm{~cm})$. Yield advantages for mid-April compared with mid-May plantings may be more evident in years when rain is abundant or in irrigated fields in Missouri. Yield advantages for mid- to late April compared with mid- to late May plantings of soybean have been reported from Texas (4) and Mississippi (8). However, Wrather et al. (24) determined that there were no differences in yields for soybean cultivars in MG IV, V, and VI between mid-April and mid-May plantings over 3 years in a nonirrigated Missouri field. There may be some benefits of early planting, including earlier maturity and, consequently, earlier harvest dates. Harvest then may be spread out over time for more efficient use of labor and machinery.

Seed harvested from early- to mid-April plantings of MG III and IV cultivars in Missouri and regions further south may not be suitable for planting due to low germination $(8,14)$. Seed of these cultivars planted in April develop and mature during the hot summer months, and infection by Phomopsis spp. can be a problem $(13,14,22,24)$. However, low germination may be due to factors other than Phomopsis spp. infection of seed. Our results also indicated that germination of Phomopsis spp.-resistant soybean lines that were planted in mid-April and matured during the hot summer was low. Mayhew and
Caviness (14) determined that germination of seed from Phomopsis spp.-resistant soybean line PI 417479 planted in midApril was very low (50\% in 1989 and 1990). Keigley and Mullen (12) concluded that low germination of seed from plants exposed to high day and night temperatures from R5 to maturity was associated with heat stress and not infection with Phomopsis spp.

We observed no correlation between percent oil or percent protein in seed and percentage of these seed infected with Phomopsis spp. Hepperly and Sinclair (10) observed significantly greater percent oil and percent protein in seed with symptoms of Phomopsis sojae infection. We have no explanation for differences between their data and ours. Bradley et al. (5) reported a significant relationship between incidence of seed infected with Phomopsis spp. and concentration of protein or oil within soybean seed at Champaign, IL in 1999 but not 1998 and not at Urbana, IL in 1998 or 1999. They did observe greater percent harvested seed infected with Phomopsis spp. in most cultivars at Champaign in 1999 than in 1998. They suggested that the severity of infection, which is influenced by environment, could play a role in determining how seed protein and oil are affected by infection by Phomopsis spp.

This is the first report of significant correlation between percent harvested seed infected with Phomopsis spp. and fatty acid composition of seed. This altered composition of fatty acids may be responsible for reduced quality of oil derived from seed infected with Phomopsis spp. Hepperly and Sinclair (10) reported that oil from seed with symptoms of $P$. sojae infection was visibly darker and had

Table 3. Year and soybean cultivar effects on percent Phomopsis sp. infection of seed and germination of harvested seed averaged over planting dates ${ }^{\mathrm{Z}}$

\begin{tabular}{lccc}
\hline & \multicolumn{3}{c}{ Cultivars } \\
\cline { 2 - 4 } Year & Asgrow 3834 & SS 93-6012 & SS 93-6181 \\
\hline Seed infection (\%) & $20.3 \mathrm{~b}$ & $1.8 \mathrm{~d}$ & $2.5 \mathrm{~d}$ \\
1998 & $30.2 \mathrm{a}$ & $4.7 \mathrm{c}$ & $3.1 \mathrm{~cd}$ \\
2000 & & & \\
Germination & $75.3 \mathrm{c}$ & $84.8 \mathrm{ab}$ & $89.1 \mathrm{a}$ \\
1999 & $47.3 \mathrm{~d}$ & $77.1 \mathrm{bc}$ & $88.4 \mathrm{a}$ \\
2000 & &
\end{tabular}

${ }^{\mathrm{z}}$ Planting dates were 15 April, 15 May, and 15 June 1998; 16 April, 17 May, and 14 June 1999; and 21 April, 16 May, and 15 June 2000. Percent Phomopsis sp. infection of seed data were collected for 1998, 1999, and 2000, but infection was extremely low for all plots in 1999 and these data were not included in this analysis. Values followed by the same letter are not significantly different $(P=0.05)$.

Table 4. Year and planting date effects on yields $\left(\mathrm{Mg} \mathrm{ha}^{-1}\right)$, percent Phomopsis sp. infection of seed, and germination of harvested seed averaged over cultivars ${ }^{\mathrm{z}}$

\begin{tabular}{lccc}
\hline & \multicolumn{3}{c}{ Planting date } \\
\cline { 2 - 4 } Year & mid-April & mid-May & mid-June \\
\hline Yields $\left(\mathrm{Mg} \mathrm{ha}^{-1}\right)$ & $0.95 \mathrm{de}$ & $0.93 \mathrm{de}$ & $0.99 \mathrm{~d}$ \\
1998 & $0.57 \mathrm{ef}$ & $0.49 \mathrm{f}$ & $0.53 \mathrm{f}$ \\
1999 & $2.75 \mathrm{a}$ & $2.47 \mathrm{~b}$ & $1.89 \mathrm{c}$ \\
2000 & & & \\
Seed infection (\%) & $8.8 \mathrm{bc}$ & $7.4 \mathrm{c}$ & $3.3 \mathrm{~d}$ \\
1998 & $19.1 \mathrm{a}$ & $11.6 \mathrm{~b}$ & $2.7 \mathrm{~d}$ \\
2000 & $77.2 \mathrm{~b}$ & $77.3 \mathrm{~b}$ & $94.7 \mathrm{a}$ \\
Germination & $50.3 \mathrm{c}$ & $73.0 \mathrm{~b}$ & $89.6 \mathrm{a}$ \\
1999 & & & \\
2000 & & &
\end{tabular}

${ }^{\mathrm{z}}$ Cultivars were Asgrow 3834, line SS 93-6012, and line SS 93-6181. Percent seed infected with Phomopsis sp. was extremely low for all treatments in 1999, and data were excluded from the analysis. Values followed by the same letter are not significantly different $(P=0.05)$.

Table 5. Pearson correlation coefficients between quality parameters for Asgrow 3834 seed harvested from mid-April planting and percentage of these seed infected with Phomopsis spp. ${ }^{\mathrm{Z}}$

\begin{tabular}{lcc}
\hline Seed quality parameter & Pearson correlation coefficient & Probability \\
\hline Percent oil & 0.4208 & 0.2991 \\
Percent protein & -0.0914 & 0.8295 \\
Percent germination & -0.8903 & 0.0030 \\
Palmitic acid composition & -0.7564 & 0.0298 \\
Stearic acid composition & -0.0667 & 0.8752 \\
Oleic acid composition & -0.8306 & 0.0106 \\
Linoleic acid composition & 0.8839 & 0.0036 \\
Linolenic acid composition & 0.7879 & 0.0202 \\
\hline
\end{tabular}

${ }^{\mathrm{z}} N=8$. 
an unpleasant, rancid odor compared with oil from seed without symptoms. They believed that damage to seed coat tissue (fissuring) due to Phomopsis sp. infection may expose the underlying tissue to air and consequent oxidation of lipids which does occur when soybean seed are dehulled (1). We determined that linolenic acid levels increased as percentage of seed infected with Phomopsis spp. increased, and high levels of this fatty acid are considered responsible for poor flavor and undesirable odors in soybean oil (3). Declines in palmitic and oleic acid levels due to infection of seed by Phomopsis spp. may influence the human health benefits of oil from these seed. Palmitic acid declined as percentage of seed infected with Phomopsis spp. increased and lower levels of this fatty acid are beneficial to humans. It has been shown to increase LDL levels, which are associated with increased heart disease (11). The lower levels of oleic acid are not desirable because increased levels of this monosaturated fatty acid may be beneficial for human nutrition (23).

This is the first report of successful management of Phomopsis seed decay in MG III and IV soybean cultivars planted in April in the south. This was accomplished by planting soybean lines SS 93-6012 and SS 93-6181, which are resistant to infection by this pathogen. All plots in our experiment were harvested when mature. The effects of delayed harvest on the percentage of lines SS 93-6012 and SS 93-6181 infected with Phomopsis spp. have not been determined. However, these lines yield well and will be useful in breeding programs focused on developing high yielding Phomopsis spp.-resistant cultivars.

\section{ACKNOWLEDGMENTS}

We thank J. Elrod for her efforts in this project.
LITERATURE CITED

1. Bailey, A. E. 1964. Industrial Oil and Fat Products. Wiley Interscience, New York.

2. Barnett, H. L., and Hunter, B. B. 1998. Illustrated Genera of Imperfect Fungi, 4th ed. American Phytopathological Society, St. Paul, MN.

3. Beare-Rogers, J. 1995. Food fats and fatty acids in human nutrition. Pages 1-7 in: Development and Processing Vegetable Oils for $\mathrm{Hu}-$ man Nutrition. R. Przybylski and B. E. McDonald, eds. AOCS, Champaign, IL.

4. Bowers, G. R. 1995. An early soybean production system for drought avoidance. J. Prod. Agric. 8:112-119.

5. Bradley, C. A., Hartman, G. L., Wax, L. M., and Pedersen, W. L. 2002. Quality of harvested seed associated with soybean cultivars and herbicides under weed-free conditions. Plant Dis. 86:1036-1042.

6. Copeland, L. D., ed. 1981. Rules for Testing Seeds. Association of Official Seed Analysts, Stone Printing Co, Lansing, MI.

7. Gomez, K. A., and Gomez, A. A. 1984. Statistical Procedures for Agriculture Research, 2nd ed. John Wiley \& Sons, New York.

8. Heatherly, L. G. 1996. Yield and germinability of seed from irrigated and nonirrigated early and late planted MG IV and V soybean. Crop Sci. 36:1000-1006.

9. Heatherly, L. G. 1999. Early soybean production system (ESPS). Pages 103-118 in: Soybean Production in the Midsouth. L. G. Heatherly and H. F. Hodges, eds. CRC Press, Boca Raton, FL.

10. Hepperly, P. R., and Sinclair, J. B. 1978. Quality losses in Phomopsis-infected soybean seeds. Phytopathology 68:1684-1687.

11. Hu, F. B., Stampfer, M. J., Mason, J. E., Rimm, E., Colditz, G. A., Rosner, B. A., Hennekens, C. H., and Willett, W. C. 1997. Dietary fat intake and the risk of coronary heart disease in women. N. Eng. J. Med. 337:14911499.

12. Keigley, P. J., and Mullen, R. E. 1986. Changes in soybean seed quality from high temperature during seed fill and maturation. Crop Sci. 26:1212-1216.

13. Kmetz, K. T., Schmitthenner, A. F., and Ellett, C. W. 1978. Soybean seed decay: prevalence of infection and symptom expression caused by Phomopsis sp., Diaporthe phaseolorum var. sojae, and D. phaseolorum var. caulivora.
Phytopathology 68:836-840.

14. Mayhew, W. L., and Caviness, C. E. 1994 Seed quality and yield of early-planted, shortseason soybean genotypes. Agron. J. 86:1619.

15. Minor, H. C., Brown, E. A., Doupnik, B., Jr., Elmore, R. W., and Zimmerman, M. S. 1993. Registration of Phomopsis seed decay resistant soybean germplasm MO/PSD-0259. Crop Sci. 33:1105.

16. Rebetzke, G. J., Burton, J. W., Carter, T. E., Jr., and Wilson, R. F. 1998. Genetic variation for modifiers controlling reduced saturated fatty acid content in soybean. Crop Sci. 38:303-308.

17. Savoy, B. R., Cothran, J. T., and Shumway, C. R. 1992. Early-season production systems utilizing indeterminate soybean. Agron. J. 84:394-398.

18. Saxton, A. M. 1998. A macro for converting mean separation output to letter groupings in Proc Mixed. Pages 1243-1246 in: Proc. 23rd Annual SAS Users Group Int. Conf. SAS Institute, Cary, NC.

19. Sinclair, J. B. 1993. Phomopsis seed decay of soybeans-a prototype for studying seed disease. Plant Dis. 77:329-334.

20. Sinclair, J. B. 1999. Diaporthe-Phomopsis complex. Pages 31-32 in: Compendium of Soybean Diseases, 4th ed. G. L. Hartman, J. B. Sinclair, and J. C. Rupe, eds. American Phytopathological Society Press, St. Paul, MN.

21. Taylor, O. 1999. ESPS method moves north. Soybean Dig. 59:26-28.

22. Tekrony, D. M., Egli, D. B., Balles, J., Tomes, L., and Stuckey, R. E. 1984. Effect of date of harvest maturity on soybean seed quality and Phomopsis sp. seed infection. Crop Sci. 24:189-193.

23. Wilson, R. F. 1991. Advances in genetic alteration of soybean oil composition. Pages 38-52 in: Designing Value-Added Soybean Markets for the Future. R. F. Wilson, ed., AOCS, Champaign, IL.

24. Wrather, J. A., Kendig, S. R., Wiebold, W. J. and Riggs, R. D. 1996. Cultivar and planting date effects on soybean stand, yield, and Phomopsis sp. seed infection. Plant Dis. 80:622624.

25. Wrather, J. A., Stienstra, W. C., and Koenning, S. R. 2001. Soybean disease loss estimates for the United States from 1996 to 1998. Can. J. Plant Pathol. 23:122-131. 